\title{
Legal and Political Consequences of Threshold Application in The General Election System in Indonesia
}

\author{
Erga Yuhandra', Haris Budiman ${ }^{2}$, Suwari Akhmaddhian ${ }^{3}$ \\ Faculty of Law, University of Kuningan, Indonesia ${ }^{123}$ \\ \{erga.yuhandra@uniku.ac.id\}
}

\begin{abstract}
General election is a mechanism of orderly circulation of power within a country. In a representative democracy system, the circulation of power is determined by elections. General elections are a concrete answer to people's participation in determining leaders and representatives in state institutions and are a symbol of people's sovereignty in a democratic system. It is feared that there is a threshold in the general election system in Indonesia that can reduce the level of democracy from the freedom to choose the best leader, besides that the existence of a threshold can reduce people's political aspirations. The purpose of this research is to find out and examine the legal and political consequences of the implementation of the threshold system in general elections in Indonesia. The research method used in this research is the normative juridical approach or also known as doctrinal law research or library research. In written legal normative legal research, it is studied from various aspects such as aspects of theory, philosophy, comparison, structure / composition, consistency, general explanation and explanation of each article, and the binding strength of a law and the language used is legal language. The use of doctrinal legal research is to find out whether and how the law regulates a matter and how the rule of law is applied
\end{abstract}

Keywords: Law; Politics; Democracy; General Election.

\section{Introduction}

Democracy is a system that is able to rise phenomenally after being lost for thousands of years. There is almost no system that can do this, especially since the rise of democracy has become a big current sweeping the world so that it is now considered a popular system and is considered the best in regulating the relationship between the people and the rulers [1]. Almost no government system is willing to accept the label undemocratic, so there is almost no government system that does not run general elections. For a number of countries that implement or claim to be democratic countries (sovereignty of the people), elections are considered as a symbol as well as the main measure of democracy. That is, the implementation and results of the general elections are a reflection of the atmosphere of openness and application of the basic values of democracy, in addition to the need for freedom of opinion and association which are considered reflections of the opinions of citizens [2].

General elections are an important instrument in any democratic country that adheres to a representative system, elections are a tool that functions to filter out politicians who will represent and bring people's voices in representative institutions. So, for those who are elected are considered as people or groups who have the ability or obligation to speak and act on 
behalf of a larger group through political parties. Therefore, the existence of a political party is a necessity in modern democratic political life. One of the characteristics of a democratic country is the holding of free general elections. General election is a political means to realize the will of the people in terms of electing their representatives in the legislative body and electing executive power holders, be it president or vice president and even regional head elections [3].

The general elections for the President and Vice President have been regulated and simplified into a new law, namely Law Number 7 of 2017 concerning General Elections. Even so, the content of the regulation is more or less still adopting Law Number 42 of 2008 concerning the General Election of the President and Vice President, one of which still contains the Presidential Threshold. The Decision of the Constitutional Court Number 14 / PUUXI / 2013 regarding the 2019 Concurrent General Elections (Pemilu) granted most of the applications except for the provisions of Article 9 of Law Number 42 of 2008 concerning the General Election of the President and Vice President regarding the Presidential Threshold which contains "Presidential and Vice Presidential candidate pairs must be proposed by a political party or coalition between political parties participating in the elections that meet the requirements for obtaining seats for at least $20 \%$ (twenty percent) of the number of seats in the DPR or obtaining $25 \%$ (twenty five percent) of the total valid national votes in the Election for DPR members, before the implementation of the Presidential and Vice-Presidential Election "[4].

With the application of thresholds in general elections in Indonesia, some think that this is part of the need for simplification of political parties so that there are not too many. Meanwhile, another opinion argues that the application of the threshold does not fulfill the values of justice in accordance with the objectives of the law. This is because the threshold, both the parliamentary threshold and the presidential threshold mathematically and normatively limits a person's right to be elected and elected in the election contest. More than that, the pros and cons of applying the threshold also give rise to a new point of view regarding the mathematical calculation of the threshold. [5] Based on the explanation above, the subject matter will be the main focus of this research, namely what are the legal and political consequences of applying thresholds in general elections in Indonesia.

\section{Method}

The research method used in this paper is the normative juridical approach or also known as doctrinal law research or library research. It is called doctrinal law research because this research is only aimed at written regulations so that this research is very closely related to the library because it will require secondary data in the library. In written legal normative legal research, it is examined from various aspects such as aspects of theory, philosophy, comparison, structure / composition, consistency, general explanation and explanation of each article, formality and binding strength of a law and the language used is legal language. One of the uses of legal research is to find out whether and how the law regulates a matter and how the legal rule is applied. The materials that have been successfully obtained or collected will then be presented selectively and systematically, the next step is that the data is analyzed using the descriptive analysis method, meaning that all legal materials that have been collected are used to describe the problem and at the same time solve it and be carried out qualitative normative. 


\section{Result and Discussion}

\subsection{The basic concept of threshold limits in the general election system in Indonesia}

Indonesia is a country with people's sovereignty in running the government. It is the people who have the power to determine the style and method of government to be carried out. In practice, those who exercise the people's sovereignty are the people's representatives who sit in the parliament. This is based on the system of people's sovereignty represented (indirect democracy). Election as a means of elite circulation to elect people's representatives is an important feature that must be carried out periodically within a certain period of time in a democratic country.

In general, the definition of a threshold is understood as the minimum limit of support or votes that must be owned to obtain certain rights in an election. In terms of function and use, the application of the threshold is to reduce the number of election participants, the number of political parties sitting in representative institutions, and the number of political parties / political parties in the presidential and vice presidential candidacy. As for the kinds of thresholds in the general election system, namely: [6]

a. Electoral Threshold is defined as the minimum level of support a party needs to gain representation in the legislature (the minimum level of support which a party needs to gain representation in the legislature). The threshold can be an amount, a percentage or a quota. This threshold is used as a condition for parties in the current election to participate in the next election.

b. Parliamentary Threshold is the threshold for seat acquisition by parties in the parliament or the House of Representatives (DPR). In other words, the Parliamentary Threshold is the minimum vote threshold for political parties in the election to be included in determining seat acquisition in the DPR.

c. Presidential Threshold as the threshold for the votes obtained by political parties in an election to be able to nominate a presidential candidate.

In Indonesia itself, in carrying out the general election process to elect representatives of the people who sit in the parliament using the parliamentary threshold as a condition so that the votes of political parties can be converted into seats in the DPR. Parliamentary Threshold is a threshold requirement for a political party's vote acquisition to enter parliament, so after the results of the total number of votes of each political party are known, then the number of votes is divided nationally. Meanwhile, in the election of the President / Vice President it uses the presidential threshold, meaning that political parties can carry the president / vice president if they meet the threshold requirements.

\subsection{Legal and political consequences of applying thresholds in the general election system in Indonesia \\ Juridical, the implementation of general elections in Indonesia is regulated in Law Number 7 of 2017 concerning General Elections, which regulates the parliamentary threshold stipulated in Article 414 of Law Number 7 of 2017 states that: \\ Political parties participating in the election must meet the threshold for obtaining votes at least four percent of the number of valid votes nationally to be included in determining the seat acquisition for DPR members.}

Meanwhile the threshold for presidential and vice presidential elections is regulated in Article 222 of Law Number 7 of 2017 which states that: 
Candidate Pairs are proposed by Political Parties or Joint Election Contesting Political Parties that meet the requirements for obtaining seats at least $20 \%$ (twenty percent) of the total seats in the DPR or obtaining $25 \%$ (twenty-five percent) of the valid votes nationally in the previous General Election for DPR members.

Legally, the application of thresholds in general elections in Indonesia has consequences that contradict several articles including:

a. Article 1 (2) of the 1945 Constitution of the Republic of Indonesia states that sovereignty is in the hands of the people and is exercised according to the Constitution;

b. Article 22 E (1) of the 1945 Constitution of the Republic of Indonesia states that general elections are held directly, publicly, freely, secretly, honestly and fairly every five years;

c. Article 27 (1) of the 1945 Constitution of the Republic of Indonesia states that all citizens have the same position in law and government and are obliged to uphold the law and government without exception;

d. Article 28 D (1) of the 1945 Constitution of the Republic of Indonesia states that everyone has the right to just legal recognition, guarantee, protection and certainty as well as equal treatment before the law;

e. Article 28 D (3) of the 1945 Constitution of the Republic of Indonesia states that every citizen has the right to equal opportunities in government;

f. Article 24 (2) Law Number 39 Year 1999 states that every citizen or community group has the right to establish a political party, non-governmental organization or other organization to participate in the running of government and state administration in line with demands for protection, enforcement and promotion of human rights in accordance with the provisions of laws and regulations.

Based on the above provisions, legally with the existence of a threshold in general elections in Indonesia it can be contrary to the provisions of the laws and regulations and can reduce the basic rights of citizens which are inherently human, universal and lasting, therefore must be protected, be respected, defended, and must not be ignored, diminished, or taken away by anyone. As for the political consequences with the application of thresholds in general elections in Indonesia, namely:

a. Only major parties can qualify and have seats in parliament;

b. Small parties will naturally find it difficult to maintain their existence;

c. The party that wins the general election has the opportunity to nominate the presidential and vice presidential candidates without having to form a coalition;

d. The potential for power is very large, given the very large number of seats in parliament, and the stability of the government will be well maintained.

Thus, politically, the application of thresholds in general elections in Indonesia only benefits parties with a large base, so that political parties that can be categorized as parties with small bases cannot voice their aspirations politically because they do not have seats in parliament.

\section{Conclusion}

Based on the results of the explanation above, the writer can conclude that juridical or legally, the application of thresholds in general elections in Indonesia has the potential to 
conflict with the basic rights of citizens guaranteed by the constitution and law. Meanwhile, politically, the application of the threshold has the consequence that only the large parties that have the most voter base will have seats in the parliament, while the small parties will lose their existence due to the threshold policy.

\section{References}

[1] Fitra Arsil, "The Theory of Government Systems: Shifting Concepts and Mutual Contribution between Government Systems in Different Countries", PT RajaGrafindo Persada, Jakarta, 2017.

[2] Titik Triwulan, "Principles of Indonesian Constitutional Law Post Amendment to the 1945 Constitution", Cerdas Pustaka Publisher, Surabaya, 2008.

[3] Uu Nurul Huda, "Political Party Law and Elections in Indonesia", Fokusmedia, Bandung, 2018.

[4] Asep Wijaya, Rosmini, Poppilea Erwinta, "Legal Problems in the Application of the Presidential Threshold in General Elections in Indonesia", Legal Brief, Volume 16, Number 1, June 2020.

[5] Sholahuddin Al-Fatih, Application of Threshold in Elections According to the Perspective of Gustav Radbruch and Hans Kelsen, Audito Comparative Law Journal Vol. 1, Issue 2, 2020.

[6] Feri Amsari, Meaning of the Presidential Threshold in the General Election, HukumOnline.com, Tuesday 29 January 2019. 